Article

\title{
Avoidance of Food Waste from a Grocery Retail Store Owner's Perspective
}

\author{
Izabela Karolina Horoś and Tonia Ruppenthal *
}

Department of Nutritional, Food and Consumer Sciences, Hochschule Fulda-University of Applied Sciences, Leipziger Str. 123, 36037 Fulda, Germany

* Correspondence: tonia.ruppenthal@oe.hs-fulda.de

check for updates

Citation: Horoś, I.K.; Ruppenthal, T. Avoidance of Food Waste from a Grocery Retail Store Owner's Perspective. Sustainability 2021, 13, 550. https://doi.org/10.3390/ su13020550

Received: 15 December 2020 Accepted: 6 January 2021 Published: 8 January 2021

Publisher's Note: MDPI stays neutral with regard to jurisdictional clai$\mathrm{ms}$ in published maps and institutional affiliations.

Copyright: (C) 2021 by the authors. Licensee MDPI, Basel, Switzerland. This article is an open access article distributed under the terms and conditions of the Creative Commons Attribution (CC BY) license (https:// creativecommons.org/licenses/by/ $4.0 /)$.

\begin{abstract}
The aim of this paper is to examine the causes of food waste and potential prevention strategies from a grocery retail store owner's perspective. We therefore conducted a case study in a German region through semi-structured expert interviews with grocery retail store owners. From the collected responses, we applied a qualitative content analysis. The results indicated that store owners try to avoid food waste as this incurs a financial loss for them that directly affects them personally, as opposed to store managers of supermarket chains who receive a fixed salary. The main causes of food waste in the grocery retail stores in the region surveyed are expiration dates, spoilage, consumer purchasing behavior, and over-ordering of food products. The most appropriate food waste prevention strategies developed by store owners are those based on store owners' experience and their own management style, such as the optimization of sales and management strategies, including precise planning, accurate ordering, and timely price reductions on soon-to-be-expiring food products. The redistribution of food surpluses as donations to food banks, employees, and as animal feed further helps to reduce the amount of food waste, but not the financial loss. This study enhances the literature by revealing that grocery retail store owners have the ability and are willing to successfully implement and enforce food prevention strategies in their stores.
\end{abstract}

Keywords: grocery retail; store owner; food waste; food waste management; case study; expert interviews

\section{Introduction}

Sustainable change in the food value chains has become an important aspect of scientific and political discourse. Halving both the food waste at the retail and consumer levels, as well as food losses at the production and post-harvest stages are the targets set by the 17 Sustainable Development Goals of the United Nations, which are to be realized worldwide [1]. Achieving this goal is necessary to provide a sustainable food system, to ensure food and nutrition security for the estimated 9 billion population in 2050 [2].

Food waste can be measured across the different stages of the food supply chain. The Food and Agricultural Organization (FAO) of the United Nations [3] describes five such stages: agricultural production, postharvest handling and storage, processing and packaging, distribution and market, and consumption. While each different supply stage has different food waste causes, the scope of this paper is the grocery retail sector, so it only addresses the distribution and market stages.

In Germany alone, on average 12.7 million tons of food per year end up as food waste, with the theoretically avoidable proportion of food waste between 6 and 8 million tons per year [4]. The bulk of food waste is generated in private households (6.14 million tons), whereas food waste generated by the retail sector seems to be considerably less, at 0.49 million tons per year [4]. System boundaries are particularly difficult to define within the retail sector, as food waste from retail can in part be attributed to other parts of the food chains such as primary production (1.36 million tons per year) as well as processing and manufacturing (2.17 million tons per year) [4]. Although the retail sector has the lowest 
share of food waste ( $4 \%$ by mass), it has a major influence on the upstream sectors-e.g., through quality standards and returns as well as on consumers, their purchasing behavior, and their handling of food [4]. In the context of food waste prevention, it seems appropriate to investigate the grocery retail sector separately, especially given the theoretical saving potentials, the avoidable food waste in this sector is estimated at $84 \%$ [4]. According to the FAO [3], avoidable food waste is food waste that, if properly handled and prepared, could have been consumed safely by humans at the time of disposal $[5,6]$.

For a better understanding of the food waste causes in the grocery retail sector within Germany, it is important to know the grocery market structure and retail landscape. The German grocery market is the largest food market in Europe and the fourth largest industry sector in Germany [7]. Five grocery retailer groups dominate the German market holding together over $75 \%$ of the total market share: Edeka, Rewe Group, Schwarz Group, Aldi Group, and Metro Group. Edeka has the biggest market share of grocery sales with 26.8\%, followed by Rewe Group with $16.2 \%$, Schwarz Group with $16.0 \%$, Aldi Group with $11.5 \%$, and Metro Group with 4.6\% [8]. The store types are usually classified based on the sales area and the different business strategies of the retailers. Following Nielsen [9], three store types are present in Germany: hypermarkets, supermarkets, and discounters [10]. In this study, the focus is on hypermarkets and supermarkets from two of the dominant grocery retailer groups within Germany.

In a literature review on food waste in retail De Moraes et al. [11] identified various causes and prevention strategies. In order to understand these causes and prevention strategies of food waste in retail, it is important to look at the in-store food waste as well as the management involved in the grocery retail stores [12]. Store managers play an important role in food waste avoidance in the grocery retail sector [12-16] since they are the ones responsible for food waste generation due to their managerial decision power [12,17]. This finding is based on food waste investigations in retail by researchers who relied mainly on employed retail managers as a source of information $[15,16,18,19]$. For research purposes, grocery retail store owners are rarely involved in the root cause analysis of food waste and the study of their prevention strategies. However, this particular group of people has not only a deep understanding of the store operations and processes but also is responsible for the entire in-store management, i.e., it bears the entrepreneurial risk and therefore has the autonomy to independently implement preventive strategies when identifying causes of food waste, without having to ask permission from the grocery retailers headquarter $[15,16]$. The opinion of grocery retail store owners could be a crucial contributor to research on food waste avoidance in grocery retail stores.

The aim of this paper is therefore to investigate qualitatively the causes of food waste in the German grocery retail sector whilst exploring the managerial attitudes, approaches, and prevention strategies particular to grocery retail store owners, as well as how they deal with the problem of food waste. In addition, this research aims to highlight the opportunities and challenges that store owners face when dealing with food waste. The qualitative method suits the research questions to identify the main causes of food waste from a grocery retail store owners' perspective and their current practices to reduce or prevent food waste. A closer look on food waste aspects as well as the approaches to food waste minimization from a grocery retail store owner's perspective brings new insights to food waste avoidance in the retail sector as well as managerial research.

The next section of this paper represents a literature review on food waste in the retail sector purely focusing on retail managers as information source. Then the materials and methods applied are described. Section 4 highlights the results of the study, which are simultaneously discussed in this section. The paper completes with conclusions in Section 5 .

\section{Literature Review}

Food waste in retail has been extensively studied and discussed in the literature and by experts [11]. The causes of food waste and prevention strategies in the grocery retail sector 
are manifold. Obtained from a literature review (see Table 1), the main causes of food waste in the grocery retail sector from a managerial perspective are linked to undesirable consumer behavior, poor consumer awareness, and retail owners financial goals [15,17-19]. As a result, conventional retailers do not list, or they exclude agricultural products with visual impairments from their product range, as they could provoke negative consumer reactions leading to additional food waste [20].

From a consumer's point of view, it is desired that the shelves are constantly filled with food products at all times, which generates over-ordering and overstocking of food products in the grocery stores $[19,21]$. These contribute to food waste because over-ordered and overstocked food products must be discarded when they are past their shelf life [2,22]. Managers have difficulty predicting and controlling incoming and outgoing goods to quite accurate levels, especially for food products with short shelf life and low inventory turnover rates $[2,21]$. In addition, some causes of food waste at the store level are hard to control for, such as weather or unexpected drops in demand [17]. Here, accurate demand forecasting and recording procedures in the store, that is to say the right food waste management and assessment can help to prevent food waste generation [23]. A standardized recording procedure can also sensitize employed store managers and the other employees to the problem of food waste and prevent further food waste [24,25]. These human factors are related to the organizational management of the grocery store $[15,16,18]$. The better trained the employed managers and the other employees are, the better work routines can be optimized [18]. Causes of incorrect handling of food products can also be reduced due to this $[23,26]$.

The amounts and types of food waste generated in retail have been studied in detail, yet food waste quantities are not always documented $[23,25]$. Nevertheless, the studies addressed that a wide range and quantity of food products and the size of the store can contribute to food waste $[15,18]$. Almost all studies come to similar conclusions regarding the food types that account for the highest share of food waste. The food commodities that are mostly wasted include fruits, vegetables, meats, and bread $[2,19,25]$.

Further managerial preventive strategies such as selling for a lower price or donations are common strategies in retail $[12,27]$. Consumers accept such strategies since the products are sold at appropriate discounts or are even donated [28]. A possible prevention strategy for over-ordered and overstocked food products is a price reduction that consumers will accept if the discount is reasonable $[20,26,28]$. Furthermore, a common strategy in retail to get rid of the overstocks is donating $[20,26,27]$. The main food waste prevention strategies used by the grocery retailers in the literature reviewed are food donations supporting charitable institutions and people in need $[2,19,26,29]$. In order to donate, collaborations must be established and legal conditions must be met [27]. Only then can the donation of food surpluses also be applied as a prevention strategy [16].

When it comes to prevention strategies and proposing actions in food waste avoidance, it is believed that employed store managers are mainly responsible to take actions and implement these strategies to reduce food waste [15-17]. Only one study has shown that food waste is dependent on who owns the grocery retail store [12]. Looking at the people and management involved in retail food waste, so far only recently this one study considered store owners as an information source [12], although it is stated in various papers that a level of autonomy could be an important factor in reducing food waste $[15,16]$. When employed store managers are given flexibility by the parent retailer, personal proactivity, and autonomy seem to be effective approaches for the reduction of food waste $[12,16,17]$. It is an important question whether also grocery retail store owners can decisively contribute to food waste avoidance and develop and implement preventive strategies. This is examined below. 
Table 1. Literature review.

\begin{tabular}{|c|c|c|c|c|c|c|}
\hline Authors (Year) & Information Source & Country & Main Variables & Methodology & Study Aim & Main Findings \\
\hline $\begin{array}{l}\text { Bilska, B.; Piecek, } \\
\text { M.; Kołożyn- } \\
\text { Krajewska, D. } \\
\text { (2018) }\end{array}$ & $\begin{array}{c}\text { Product } \\
\text { management }(n=1)\end{array}$ & Poland & $\begin{array}{l}\text { Food products, digital } \\
\text { code, product name, } \\
\text { mass, quantity, net } \\
\text { purchase price, } \\
\text { percentage structure of } \\
\text { waste, and estimation of } \\
\text { financial losses }\end{array}$ & $\begin{array}{c}\text { Handwritten } \\
\text { information, statistical } \\
\text { data analysis (Excel) }\end{array}$ & $\begin{array}{l}\text { Food waste generated in } \\
\text { terms of its mass, financial } \\
\text { value, and wasted caloric } \\
\text { value to find ways to reduce } \\
\text { food waste in commercial } \\
\text { facilities }\end{array}$ & $\begin{array}{l}\text { Two weeks: } \sim 3.3 \text { tons of food waste } \\
(\sim 5500 €) \\
\text { Products with highest percentage share of } \\
\text { food waste: fruits, vegetables, meats, cold } \\
\text { meats, and fish }\end{array}$ \\
\hline $\begin{array}{l}\text { Cicatiello, C.; } \\
\text { Franco, S.; } \\
\text { Pancino, B. } \\
\text { (2017) }\end{array}$ & $\begin{array}{c}\text { Product } \\
\text { management }(n=1)\end{array}$ & Italy & $\begin{array}{l}\text { Edible and discarded } \\
\text { food items, food groups, } \\
\text { item codes and } \\
\text { descriptions, and } \\
\text { quantity discarded and } \\
\text { their costs }\end{array}$ & $\begin{array}{c}\text { Meta-analysis, } \\
\text { collecting and } \\
\text { analyzing the food } \\
\text { waste stream }\end{array}$ & $\begin{array}{l}\text { Quantification of in-store } \\
\text { food waste focusing on } \\
\text { edible and inedible fraction }\end{array}$ & $\begin{array}{l}\text { One year: } 70.6 \text { tons of food waste } \\
(\sim 170,000 €) \\
\text { - } \quad \text { Food waste: bread, fresh fruit, and } \\
\text { vegetables } \\
\text { - } \quad \text { Edible fraction: } 35 \% \text { of total food waste } \\
\text { Gaps exist in food waste recording } \\
\text { procedure }\end{array}$ \\
\hline $\begin{array}{l}\text { Cicatiello, C.; } \\
\text { Blasi, E.; } \\
\text { Giordano, C.; } \\
\text { Martella, A.; } \\
\text { Franco, S. } \\
\quad \text { (2020) }\end{array}$ & $\begin{array}{c}\text { Food category } \\
\text { managers }(n=67)\end{array}$ & Italy & $\begin{array}{l}\text { Quantity and value of } \\
\text { food waste, technical } \\
\text { issues, human-related } \\
\text { issues, customers' } \\
\text { behavior, sales } \\
\text { management, store } \\
\text { management, and other }\end{array}$ & $\begin{array}{l}\text { Mixed method: } \\
\text { quantification and } \\
\text { qualification study } \\
\text { (focus groups with } \\
\text { survey and sticky } \\
\text { notes) }\end{array}$ & $\begin{array}{l}\text { Ascertain food waste causes } \\
\text { and possible prevention } \\
\text { initiatives from individuals } \\
\text { who are familiar with } \\
\text { behind-the-scenes } \\
\text { operations in retail stores }\end{array}$ & $\begin{array}{l}\text { In-store operations are responsible for } \\
\text { retail food waste } \\
\text { - Store managers are mainly responsible for } \\
\text { the implementation of waste reduction } \\
\text { actions } \\
\text { - Food category managers are key actors in } \\
\text { reducing retail food waste }\end{array}$ \\
\hline $\begin{array}{l}\text { Cicatiello, C.; } \\
\text { Franco, S. } \\
\quad(2020)\end{array}$ & $\begin{array}{c}\text { Product } \\
\text { management }(n=13)\end{array}$ & Italy & $\begin{array}{l}\text { Suboptimal products } \\
\text { and destinations as } \\
\text { waste per food category }\end{array}$ & $\begin{array}{l}\text { Standard waste } \\
\text { recording, one-tailed } \\
t \text {-test, linear regression, } \\
\text { ANOVA model }\end{array}$ & $\begin{array}{l}\text { Improved recording practice } \\
\text { to detect food wasted }\end{array}$ & $\begin{array}{l}\text { Accurate recording procedure sensitizes } \\
\text { for food waste and may prevent to some } \\
\text { extent its generation } \\
\text { Proposal of a new model of food waste } \\
\text { recording }\end{array}$ \\
\hline
\end{tabular}


Table 1. Cont.

\begin{tabular}{|c|c|c|c|c|c|c|}
\hline Authors (Year) & Information Source & Country & Main Variables & Methodology & Study Aim & Main Findings \\
\hline $\begin{array}{l}\text { Filimonau, V.; } \\
\text { Gherbin, A. } \\
\text { (2017) }\end{array}$ & $\begin{array}{l}\text { Retail store managers } \\
\qquad(n=12)\end{array}$ & $\begin{array}{l}\text { United } \\
\text { Kingdom }\end{array}$ & $\begin{array}{l}\text { Barriers to food waste } \\
\text { mitigation, magnitude of } \\
\text { food waste, food waste } \\
\text { mitigation approaches }\end{array}$ & $\begin{array}{l}\text { Qualitative content } \\
\text { analysis (in-depth } \\
\text { semi-structured } \\
\text { interviews) }\end{array}$ & $\begin{array}{l}\text { How retail store managers } \\
\text { address the problem of food } \\
\text { waste in their day-to-day } \\
\text { operations }\end{array}$ & $\begin{array}{l}\text { Food waste prevention: recycling and } \\
\text { price reductions } \\
\text { - } \quad \text { Donations occur at managerial discretion } \\
\text { Poor consumer awareness, imperfect } \\
\text { regulation, inflexible corporate polices, } \\
\text { and limited control over suppliers } \\
\text { hamper food waste mitigation }\end{array}$ \\
\hline $\begin{array}{l}\text { Gruber, V.; } \\
\text { Holweg, C.; } \\
\text { Teller, C. } \\
\text { (2016) }\end{array}$ & $\begin{array}{l}\text { Retail store managers } \\
\qquad(n=32)\end{array}$ & $\begin{array}{c}\text { Developed } \\
\text { countries }\end{array}$ & $\begin{array}{l}\text { Store manager's } \\
\text { experiences with food } \\
\text { waste and its impact on } \\
\text { their stores' daily } \\
\text { realities and personal } \\
\text { lives }\end{array}$ & $\begin{array}{l}\text { Qualitative content } \\
\text { analysis (NVivo 10) } \\
\text { and semi-structured } \\
\text { interviews }\end{array}$ & $\begin{array}{c}\text { Focus on food waste in } \\
\text { logistics and operations } \\
\text { management describing the } \\
\text { what and the how (process } \\
\text { orientation) }\end{array}$ & $\begin{array}{l}\text { - Societal, regulatory, and systematic } \\
\text { constraints lead to the occurrence of food } \\
\text { waste in stores and the resulting moral } \\
\text { burden on store managers }\end{array}$ \\
\hline $\begin{array}{l}\text { Hermsdorf, D.; } \\
\text { Rombach, M.; } \\
\text { Bitsch, V. } \\
\text { (2017) }\end{array}$ & $\begin{array}{l}\text { Retail store managers } \\
\text { and food bank } \\
\text { spokesperson } \\
(n=12)\end{array}$ & Germany & $\begin{array}{l}\text { Non-standardized food } \\
\text { items in storage and } \\
\text { logistics as well as } \\
\text { dimension, } \\
\text { characteristics, and } \\
\text { quantities of products } \\
\text { with visual defects }\end{array}$ & $\begin{array}{l}\text { Qualitative content } \\
\text { analysis: in-depth } \\
\text { interviews }\end{array}$ & $\begin{array}{l}\text { Food waste reduction } \\
\text { practices focusing on selling } \\
\text { and redistributing surplus } \\
\text { food items as well as drivers } \\
\text { and barriers regarding the } \\
\text { implementation of waste } \\
\text { reduction practices }\end{array}$ & 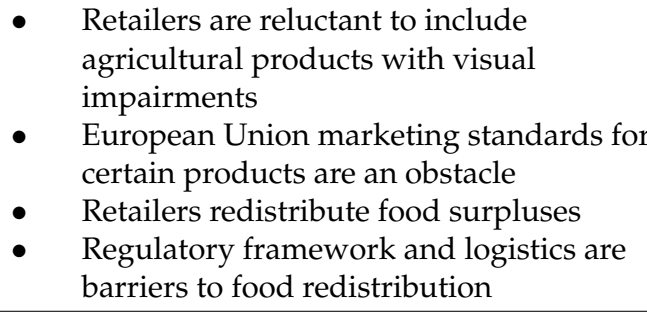 \\
\hline $\begin{array}{l}\text { Holweg, C., } \\
\text { Teller, C.; } \\
\text { Kotzab, H. } \\
\text { (2016) }\end{array}$ & $\begin{array}{c}\text { Store category } \\
\text { managers }(n=3) \\
\text { Point of sale } \\
\text { observation }(n=32) \\
\text { Secondary data } \\
\text { research }\end{array}$ & Europe & $\begin{array}{l}\text { Logistics processes and } \\
\text { activities related to } \\
\text { unsalable products on } \\
\text { the sales floor }\end{array}$ & $\begin{array}{c}\text { Embedded case study, } \\
\text { content analysis } \\
\text { approach, and } \\
\text { semi-structured } \\
\text { interviews }\end{array}$ & $\begin{array}{l}\text { Explore in store logistics } \\
\text { processes related to products } \\
\text { declared unsalable }\end{array}$ & $\begin{array}{l}\text { Optimization of in store logistics } \\
\text { processes which lead to cost savings, } \\
\text { more effective and efficient operations, } \\
\text { better use of resources, and waste } \\
\text { reduction } \\
\text { At the same time charitable institutions } \\
\text { and people in need are supported }\end{array}$ \\
\hline
\end{tabular}


Table 1. Cont.

\begin{tabular}{|c|c|c|c|c|c|c|}
\hline Authors (Year) & Information Source & Country & Main Variables & Methodology & Study Aim & Main Findings \\
\hline $\begin{array}{l}\text { Kliaugaite, D.; } \\
\text { Kruopienè, J. } \\
\text { (2017) }\end{array}$ & $\begin{array}{c}\text { Store managers } \\
\quad(n=3) \\
\text { Secondary literature }\end{array}$ & Lithuania & $\begin{array}{l}\text { Food waste in specific } \\
\text { stages or locations }\end{array}$ & $\begin{array}{c}\text { Semi-structured } \\
\text { questionnaire survey } \\
\text { and comparative study }\end{array}$ & $\begin{array}{c}\text { Food loss assessment with } \\
\text { neighboring countries in } \\
\text { North Europe to facilitate } \\
\text { food waste prevention } \\
\text { measures }\end{array}$ & $\begin{array}{l}\text { Lithuanian retail sector generates less } \\
\text { food waste as European Union average } \\
\text { but same as Estonia } \\
\text { Fruits, vegetables, and bakery products } \\
\text { dominate food waste } \\
\text { - Food waste is linked to consumer } \\
\text { behavior or shop-owners goal to sell } \\
\text { - Main prevention strategy is food donation }\end{array}$ \\
\hline $\begin{array}{l}\text { Teller, C.; } \\
\text { Holweg, C.; } \\
\text { Kotzab, H. } \\
\text { (2015) }\end{array}$ & $\begin{array}{l}\text { (Deputy) Store } \\
\text { managers or } \\
\text { merchandise } \\
\text { managers }(n=32)\end{array}$ & Europe & $\begin{array}{l}\text { Point of sale factors: } \\
\text { distribution channel, } \\
\text { store format, store size, } \\
\text { turnover, product range, } \\
\text { categories, and location }\end{array}$ & $\begin{array}{l}\text { Qualitative research } \\
\text { approach: } \\
\text { semi-structured } \\
\text { interviews and } \\
\text { secondary research }\end{array}$ & $\begin{array}{l}\text { Discussion of the relevance } \\
\text { of food waste and } \\
\text { identification of procedures } \\
\text { for redistributing edible } \\
\text { food waste to charitable } \\
\text { organizations }\end{array}$ & $\begin{array}{l}\text { Prolonging sales and distribution process } \\
\text { of products declared as food waste } \\
\text { Identification of social distribution } \\
\text { channels to make products available for } \\
\text { disadvantaged consumers } \\
\text { - } \quad \begin{array}{l}\text { New facts of corporate social } \\
\text { responsibility addressed and executed on } \\
\text { a daily base }\end{array}\end{array}$ \\
\hline $\begin{array}{l}\text { Teller, C.; } \\
\text { Holweg, C.; } \\
\text { Reiner, G.; } \\
\text { Kotzab, H. } \\
\quad(2018)\end{array}$ & $\begin{array}{l}\text { Retail and store } \\
\text { operations } \\
\text { perspective }(n=28) \\
\text { Store managers } \\
\quad(n=32) \\
\text { Food waste experts } \\
\quad(n=12)\end{array}$ & $\begin{array}{l}\text { Western } \\
\text { Europe }\end{array}$ & $\begin{array}{c}\text { Store configurations: } \\
\text { location, space (size), } \\
\text { number of categories, } \\
\text { number of stock-keeping } \\
\text { units in each category, } \\
\text { quality and pricing of } \\
\text { products, and service } \\
\text { level }\end{array}$ & $\begin{array}{l}\text { Multi-method } \\
\text { approaches: case } \\
\text { studies with } \\
\text { semi-structured } \\
\text { interviews, secondary } \\
\text { data research, and } \\
\text { process simulation } \\
\text { modeling approach }\end{array}$ & $\begin{array}{l}\text { Identification of the root } \\
\text { causes of food waste } \\
\text { occurrence }\end{array}$ & $\begin{array}{l}\text { - Food waste causes: consumer behavior, } \\
\text { inefficient store operations, replenishment } \\
\text { policies, and product (quality) } \\
\text { requirements } \\
\text { - Causes and impacts differ across store } \\
\text { - } \quad \text { Cormats and product categories } \\
\text { responsibility and influence }\end{array}$ \\
\hline
\end{tabular}


The literature review shows that grocery retailers have already adopted various approaches to reduce food waste. These approaches are closely linked to retail managers' behavior and commitment and how they handle food waste generation. The information sources in the literature reviewed were product managers (3), retail store managers (4), category or merchandise managers (4), and store owners (1). The identification of the causes of food waste is mostly based on direct observations by employed retail managers [17]. Just recently, a study also surveyed grocery retail store owners in Sweden and recommended further investigations also in other countries. Following this recommendation and since the general conclusion across the studies from the literature was, even if mostly only employed store managers were investigated, that the financial objectives of grocery retail store owners contribute to the causes of food waste [19] and that food waste could be prevented if store managers are proactive and autonomous $[16,17]$. The grocery retail store owners' perspective could be valuable in research on the avoidance of retail food waste, as they are responsible for the management of their stores and have a direct and immediate influence to change things. Grocery retail store owners in particular have a great deal of autonomy and flexibility since they can act independently from retailers headquarter, which leads to the ability to take proactive actions and implement prevention strategies to avoid food waste.

\section{Materials and Methods}

\subsection{Literature Review}

For the literature review, the databases Business Source Premium and Web of Science were searched by the authors, applying search terms such as "food waste" and "retail(er)", "food waste" and "retail stores", "food waste" and "supermarket(s)", "grocery retail" and "food waste" as well as "retail food waste management" in the title, abstract, and keywords. Furthermore, the references of found relevant articles were consulted. For inclusion in the literature review, articles had to be in English and peer-reviewed, published from 2015 onwards to incorporate an overview of recent developments and issues of food waste in the grocery retail sector from a managerial perspective. Therefore, the source of information of the study had to be managers, store managers, or similar. Furthermore, the papers had to focus purely on retail stores and their internal store operations that could be influenced by the managers. Supply chain investigations e.g., [30,31], life cycle assessment methods e.g., [32,33], consumer studies e.g., [34-36], dynamic shelf life e.g., [37] as well as environmental, social, and economic impacts of food waste e.g., $[23,38]$ at the grocery retail store level were therefore excluded. Twelve articles fulfilled these criteria (see Table 1). The literature review is presented before in Section 2.

\subsection{Case Study and Expert Interviews}

A case study approach was applied, since it is a method that is used increasingly in management research. The unit of analysis was the grocery retail sector in a region in Germany. The case involved multiple actors, e.g., different grocery retailers. Because it was not a single actor but rather a group of actors originating from the population, it is called a group design [39]. Therefore, the case of the grocery retail sector within a German region framed the extent of the research applying a multiple-case study design recommended by Yin [40], which involved embedded units such as different grocery retailers. Hypermarkets, supermarkets, and discounters are the most important formats in German grocery retailing [41]. Hypermarkets are grocery retailers with a sales area starting from $1000 \mathrm{~m}^{2}$, subdivided into small hypermarkets with a sales area of 1000 to $2499 \mathrm{~m}^{2}$ and large hypermarkets with a sales area of at least $2500 \mathrm{~m}^{2}$. Supermarkets are food retailers with a sales area of 100 to $999 \mathrm{~m}^{2}$, subdivided in small supermarkets with 100 to $399 \mathrm{~m}^{2}$ and large supermarkets with 400 to $999 \mathrm{~m}^{2}[9,10]$. Discounters are grocery retailers for whose sales policy the discount principle (e.g., low prices, limited assortment) is decisive regardless of the size of the sales area $[9,10]$. 
Discounters are excluded in this study since German discounters have no private grocery retail store owners, but are chains. The final sample consisted of four store owners and one employed store manager for sample completion. All interviewees belonged to two of the top five grocery retail companies. The store type was either a hyper- or supermarket. All five stores were conventional retailers. The case characteristics are presented in Table 2.

Table 2. Case characteristics: classification of interviewed grocery retailers.

\begin{tabular}{|c|c|c|c|c|c|c|}
\hline $\begin{array}{c}\text { Interviewee' } \\
\text { Position }\end{array}$ & $\begin{array}{l}\text { Decision } \\
\text { Making }\end{array}$ & $\begin{array}{c}\text { Location in a } \\
\text { German } \\
\text { Region }\end{array}$ & Turnover & Sales Area & Store Type & $\begin{array}{l}\text { Food Amount } \\
\text { Wasted }\end{array}$ \\
\hline Store owner & Yes & Rural district & $\begin{array}{l}\sim 350,000 € \text { per } \\
\text { month }\end{array}$ & $800 \mathrm{~m}^{2}$ & $\begin{array}{c}\text { Large } \\
\text { supermarket } \\
\text { (conventional) }\end{array}$ & $\begin{array}{c}\sim 1.4 \% \\
(\sim 5000 €)\end{array}$ \\
\hline Store owner & Yes & City center & $\begin{array}{l}\sim 400,000 € \text { per } \\
\text { month }\end{array}$ & $2000 \mathrm{~m}^{2}$ & $\begin{array}{c}\text { Small } \\
\text { hypermarket } \\
\text { (conventional) }\end{array}$ & $\begin{array}{c}\sim 2 \% \\
(\sim 8000 €)\end{array}$ \\
\hline $\begin{array}{l}\text { Store manager } \\
\text { (employed) }\end{array}$ & No & Suburb & $\begin{array}{l}\text { No data } \\
\text { provided }\end{array}$ & $2000 \mathrm{~m}^{2}$ & $\begin{array}{c}\text { Small } \\
\text { hypermarket } \\
\text { (conventional) }\end{array}$ & $\begin{array}{l}\text { No data } \\
\text { provided }\end{array}$ \\
\hline Store owner & Yes & Suburb & $\begin{array}{l}\text { No data } \\
\text { provided }\end{array}$ & $4000 \mathrm{~m}^{2}$ & $\begin{array}{c}\text { Large } \\
\text { supermarket } \\
\text { (conventional) }\end{array}$ & $\sim 0.1 \%$ \\
\hline Store owner & Yes & Rural district & $\begin{array}{l}\text { No data } \\
\text { provided }\end{array}$ & $2000 \mathrm{~m}^{2}$ & $\begin{array}{c}\text { Small } \\
\text { hypermarket } \\
\text { (conventional) }\end{array}$ & $\sim 0.1-2.5 \%$ \\
\hline
\end{tabular}

Since a research gap in managerial research on food waste in the grocery retail sector was identified in the literature review, owners of grocery retail stores were specifically targeted as key informants to gather their opinions, perspectives, and knowledge as well as their respective waste management practices. Therefore, a qualitative research design was considered as most suitable approach for knowledge generation [42]. Qualitative methods are well suited to generate in-depth insights into store operations [18]. To cover the complexity of the research and to identify relevant influencing factors for food waste generation, a qualitative method with semi-structured expert interviews was chosen. Expert interviews are particularly suitable for sensitive or difficult research topics such as this one, as owners and managers disclosed sensitive and confidential data to capture the as yet unknown context of food waste generation in the grocery retail sector from a store owners perspective within Germany [39]. The expert interviews were executed according to the given procedure by Kaiser [43]. A semi-standardized, open-interview guideline was defined following the guidelines by Gläser and Laudel [44] with different topic segments according to which the data was collected and analyzed (see Table 3). Before the actual expert interviews took place, a pre-test expert interview with a store manager of a grocery retail store (supermarket) that was not located in the investigated German region was carried out. 
Table 3. Topic segments.

\begin{tabular}{|c|c|}
\hline Topic Segments & Contents \\
\hline $\begin{array}{l}\text { Incoming and outgoing goods } \\
\text { process }\end{array}$ & $\begin{array}{ll}\text { - } & \text { Daily procedure } \\
\text { - } & \text { Recording of withdrawn food } \\
\text { - } & \text { Agreements with suppliers } \\
\end{array}$ \\
\hline Amount of food waste & $\begin{array}{l}\text { - } \quad \text { Approximate food waste amount and value in general } \\
\text { - } \quad \text { Food commodities with highest waste share }\end{array}$ \\
\hline Causes of food waste & $\begin{array}{ll} & \text { Causes of non-marketable food products } \\
\text { - } & \text { Criteria for food product withdrawal } \\
\end{array}$ \\
\hline Preventive strategies & $\begin{array}{l}\text { - } \quad \text { Strategies that are in place to reduce food waste or } \\
\text { respectively reduce the impact of food waste } \\
\text { - } \quad \text { Most effective preventive strategies } \\
\text { - } \quad \text { Procedures and assessment of food redistribution }\end{array}$ \\
\hline Food waste management & $\begin{array}{ll}\text { - } & \text { Forms and procedures of waste management } \\
\text { - } & \text { Costs of food waste management } \\
\text { - } & \text { Disposal procedures }\end{array}$ \\
\hline Food waste assessment & $\begin{array}{ll}\text { - } & \text { Self-assessment } \\
\text { - } & \text { Customer assessment } \\
\text { - } & \text { Possibilities for improvement }\end{array}$ \\
\hline
\end{tabular}

\subsection{Data Collection}

The sample was addressed via different recruiting channels such as e-mail and telephone. The first contacts with the owners of grocery retail stores were not successful due to the fact that contacted owners had the feeling they may reveal very sensitive and highly confidential data [19]. A relatively small sample was compiled on a convenience basis through personal contacts by the researchers. Convenience sampling is justified when informants are difficult to access or their population is limited, such as grocery retail store owners [15]. Possible interview partners were systematically contacted according to a grid, in which all retailers in the regional surroundings were listed and contacted one after another. Since the study took an explorative approach and the willingness of the experts to give an interview was voluntary, the selection of interview partners was not representative. The acquisition of interview partners was hindered by perceived data sensitivity. Of the 15 grocery retailers contacted in the German region, four store owners and one employed store manager were willing to participate.

The data collection from the five grocery retail managers took place from June to September 2019 and was conducted by one of the authors. The interview survey consisted of seven parts: introduction and general information, incoming and outgoing goods process, amount of food waste, causes of food waste, preventive strategies, food waste management and assessment, and a closing part. A semi-standardized questionnaire with an interview guideline was used. The interview guideline contained a table with three columns: (1) topic segments, (2) corresponding possible questions, and (3) variables. There was no order of questions and the topics were addressed through open-ended questions.

In total, all five interviews were audio recorded and transcribed verbatim following the rules described by Rädiker und Kuckartz [45]. Since all expert interviews were carried out in German language, the transcribed text was translated to a uniform English language. The complete length of the interviews is $2 \mathrm{~h}, 26 \mathrm{~min}$, and $30 \mathrm{~s}$, which resulted in 461.5 spaced A4 pages of transcripts. The interviews with the managers lasted on average $29 \mathrm{~min}$ and $9 \mathrm{~s}$ and were carried out face-to-face since the personal contact helped to build a confident and trusting environment for the sensitive managerial questions. A graphical scheme of tools applied for data collection is presented in Figure 1. 


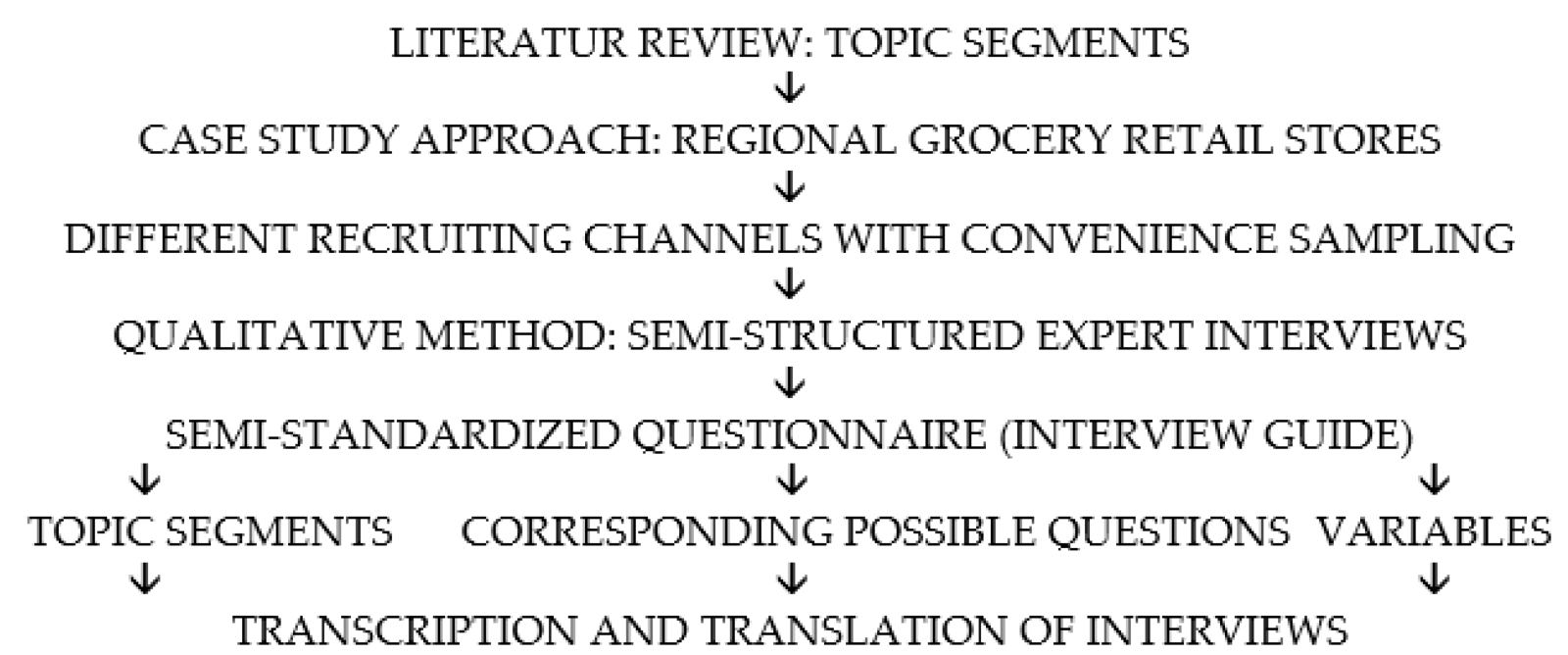

Figure 1. Graphical scheme of tools applied for data collection.

\subsection{Data Analysis}

All interview transcripts were analyzed by qualitative content analysis according to Mayring [46]. This procedure, also called coding, allows categories to emerge from textual data [47]. During the coding process the software MAXQDA was used [45] since a computer-assisted qualitative data analysis software facilitates the interpretations of qualitative data [47]. All relevant text passages were assigned to a corresponding category. The categories were represented as a hierarchy of equal terms and are the key points of the research segments. The definitions of the research key points were included in the memos of the categories. By applying these categories to the text, a system with a content structure was created. In content structuring, certain information from the communication material was filtered according to the pre-defined category system and summarized. Summarization representing an important interpretation form [46]. The coded regions were summarized by eliminating decorative and/or repetitive, clarifying phrases. The summarized data of a single category was then compared between interviews. The coding was verified multiple times, discussed, and standardized to ensure inter-coder reliability [47]. The data of the single coding was compared between the interviews. For the coding structure developed from the interviews, see Figure 2.

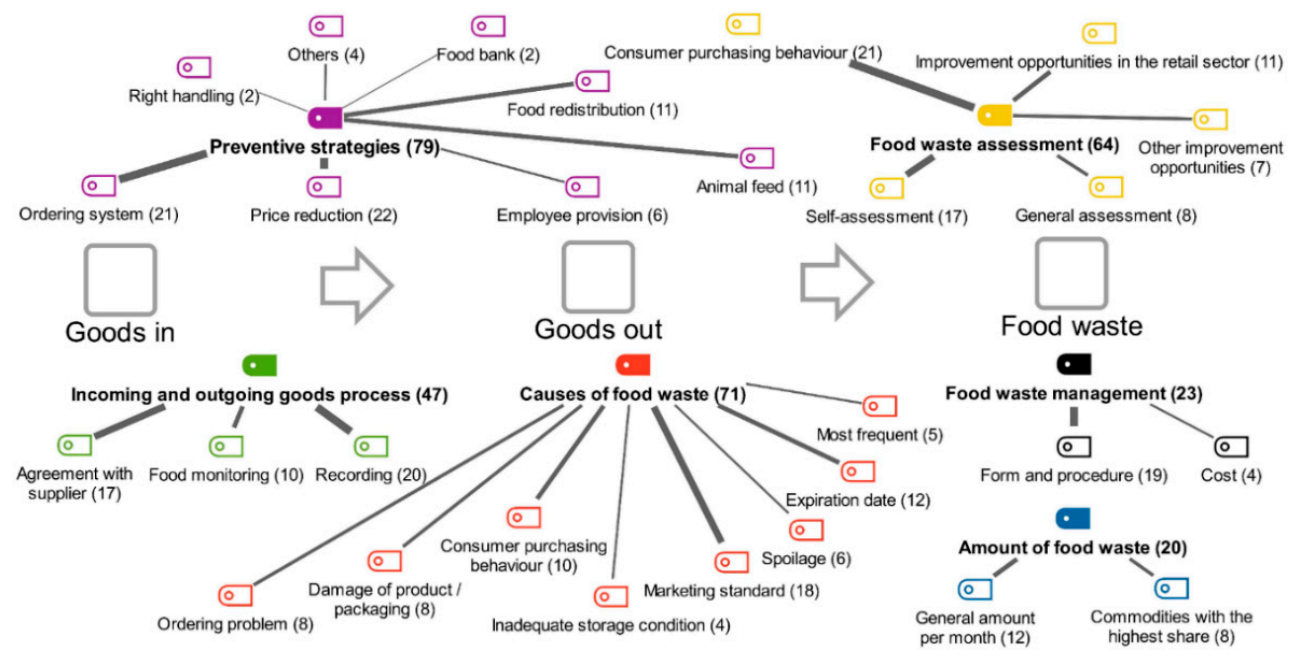

Figure 2. The coding structure developed from the expert interviews. Summary of code list with placement of codes in the food product path; bold fonts are categories; normal fonts are codes; stroke thickness shows the frequency of the codes. 


\section{Results and Discussion}

The store owners and manager in the German region primarily applied three measures to avoid food waste in their area. Firstly, the store owners, as well as the store manager, monitor the sales of food products as closely as possible and initiate the ordering process based on their experience. This includes being able to assess as correctly as possible the effects of weekly offers and the overall consumer demand taking into account seasonal effects. Trial-and-error and the gathering of management learning experiences are crucial here, with a merchandise management system providing important management support. Secondly, store owners reduce the prices of food products that are close to their expiration date in order to sell the remaining stocks, while still making a profit, and reducing food waste. The decisions to reduce prices follow a specific managerial procedure. Thirdly, as one of the last options before the food is disposed as residual waste, either the store owners try to sell of food products completely until the last day of validity, or they donate the food products to food banks, their employees, and/or as animal feed. When the store owners donate to food banks, they conduct this in a swift and orderly process so that the food bank can safely give the food to third parties. Not all store owners donate food because of the associated time and cost intensive coordination processes, or simply because they do not have enough food waste. The grocery retail store owners and manager have a key role to play in all the above mentioned points.

The results of the interviews are presented and discussed by the categories obtained through the content analysis (see Table 3). These include the incoming and outgoing goods processes, amount of food waste, causes of food waste, preventive strategies, food waste management, and food waste assessment (see Figure 2).

\subsection{Incoming and Outgoing Goods Process}

This section covers the general process at the two interfaces of the incoming and outgoing goods at the grocery retailers. The category was coded 47 times, divided into the subcategories "agreement with supplier" (17), "food monitoring" (10), and "recording" (20).

Under the most frequently occurring subcategory "agreement with supplier", mainly two different types of agreements are in place. The first type of agreement, which is also the most common form overall, involves the store owner taking full responsibility for ordering, sales, and waste management. In the second type of agreement, a kind of credit principle is installed whereby the store owners are not responsible for the disposal of the food products delivered by the suppliers (first version). If the food products have not been sold, the suppliers have to write them off on their account, adjust their delivery in the future to insure no loss of money, and redeliver the products that are missing in the store on their own account. To this end, suppliers and store owners have to maintain a two-way information exchange on the quantities of the products in the store, and the amount sold. A modified form of the second type of agreement exists (second version). Here, the responsibility for the sale of the food products lies on the side of the store owners, including the loss when the store owners can no longer sell the products. However, here, the disposal of leftover food products remains the responsibility of the supplier. In this form of agreement, store owners can lower the price of food products that are close to expiration date to still attempt to sell them and thus prevent a potential loss. In both versions, the food products are collected and sent back to the suppliers for further waste management. This means that the store owners do not produce food waste in their store. The disposal of food waste is shifted to the suppliers, but the overall waste remains. These agreements mainly cover direct marketer stocks.

The credit principle of the second type of agreement can be interpreted as critical because the store owners know that the suppliers will dispose of the food products. The store owners may pay less attention to these products, since they do not count as food waste for their store, and for the first version of this agreement, this wastage does not incur financial losses for them. In the second version, store owners are more concerned about food waste, as this could result in a financial loss for them. The credit principle could 
be a win-win situation for both parties, optimizing profits when they agree to exchange information about incoming and outgoing goods. An additional effect of this is then the reduction of food waste.

Overall, store owners have to negotiate with various suppliers and negotiate agreements with them. This is not an easy undertaking, since the communication with the suppliers varies according to distance and company size. Particularly when within the local region, communication with regional and/or small suppliers is easier and greater flexibility may be achieved when compared to suppliers from outside the local area. This finding is underlined in the studies by Mena et al. [21,48], which report that a close collaboration between retailers and supplier is necessary to reduce food losses. In addition, store owners can negotiate by themselves. The situation is different if a retail chain is involved, where the retail manager is not the owner and cannot negotiate for the supermarket itself. Food waste can be avoided on both sides if both parties work hand in hand, if an up-to-date inventory system and controlled processes are in place throughout the entire transportation process, and if the store owner has a real influence on the agreements reached with suppliers.

The subcategory "food monitoring" summarizes the monitoring process of the quality, expiration date, and tidiness of a product regularly. Here, the frequency of the monitoring can differ for each food commodity, depending on the delivery frequencies and the freshness of the products. Fresh products such as fruits, vegetables, or dairy products are checked daily. Fruits and vegetables are normally also delivered daily. The first quality controls of these two food commodities take place in the central warehouse before the delivery to the grocery retail store. Checks of dry assortments take place when a new delivery arrives or during the inventory checks. One store owner established an expiration date list of products to maintain knowledge on the quantity of food that will expire soon. This list helps the store owner decide when and by how much to lower the price of the products and when to donate to food banks.

The subcategory "recording" describes how the store owners record outgoing goods. Here, the status of the products in the store and the outgoings are evaluated and product orders are optimized. All interviewed store owners and manager used a scanner to record the respective value and quantity of the products in their merchandise management system. Three store owners additionally recorded the outgoing goods either as spoilage or as breakage. The recording is a closed merchandise management system in which it is not possible to optimize the system specifically for each store individually. This means that the system cannot differentiate between food that still can be used, for example as donations, or that has to be disposed. All groceries that cannot be sold are booked into the system, undifferentiated, as one outgoing item category. Here, the recording system could be improved by implementing a selection of destinations for the non-saleable items, for example as donations to food banks and/or to employees, as animal feed, and as residual waste [26]. By doing this, the recording system could help to record what is delivered to which destination in what quantities, to obtain a more accurate assessment of costs associated with the actual food waste.

\subsection{Amount of Food Waste}

This category was coded in total 20 times. The subcategories cover the "general amount per month" (12) as well as the "commodities with the highest share" (8). For the food commodities with the highest share, it was also coded how often the store owners and manager mentioned them. The order of priority is as follows: fruits and vegetables (56), milk and dairy (27), meat and sausages (17), dry assortment (12), bread and bakery (8), fish (5), seasonal food (2), and frozen food (2).

According to the statements of the store owners, the food waste amounts between 0.1 to $2.5 \%$ of their total monthly turnover. Two store owners indicated a value of food wasted, which amounted for the large supermarket $\left(800 \mathrm{~m}^{2}\right)$ around $5.000 €$ per month $\left(6.35 € / \mathrm{m}^{2}\right.$ of sales area) and the small hypermarket $\left(2000 \mathrm{~m}^{2}\right)$ around $8000 €$ per month $\left(4.00 € / \mathrm{m}^{2}\right.$ of 
sales area). This does not mean that $5000 €$ or $8000 €$ worth of food is discarded completely in bins. The store owners redistribute some of the food. Since the store owners and manager cannot record the destination of discarded food in their current management system, the discarded food is at present solely categorized as the total food waste.

The final disposal of food waste is associated with costs for the store owners [19]. If one compares the aforementioned average value of food waste taking into account the sales areas with studies from the literature review, it can be seen that the food waste figures in the investigated region in Germany are below those presented in the other studies. The Polish supermarket with a sales area of about $2000 \mathrm{~m}^{2}$ that Bilska et al. [2] investigated had a monthly value of food waste of $5.50 € / \mathrm{m}^{2}$. In the study by Cicatiello and Franco [24], two supermarkets with a sales area of less than $1000 \mathrm{~m}^{2}$ are estimated with a monthly value of food waste of $7.40 € / \mathrm{m}^{2}$ and $9.00 € / \mathrm{m}^{2}$ and two supermarkets with a sales area of $2000 \mathrm{~m}^{2}$ are estimated with a monthly value of food waste of $4.00 € / \mathrm{m}^{2}$ and $4.60 € / \mathrm{m}^{2}$. For the region in Germany investigated in the current study, one can argue that the store owners might score better than those mentioned in the literature review since this study focuses on owners of grocery retail stores. These store owners are more flexible in their managerial behavior than retail managers of supermarket chains, where orders come directly from the headquarters. Furthermore, the managerial decisions made on a regional scale and the regional agreements may have a direct impact on food waste. This is supported by Gruber et al. [16], who stated that the larger the flexibility provided by an organization and the more autonomy the retail managers have, the more empowered they feel to take proactive measures. It could also be that the store owners did not reveal all their cost saving strategies in the interview.

From two studies from the literature review $[2,24]$ and from this current study, it seems that the smaller the sales area of the grocery retailer, the higher percentage of food products are wasted. Apparently, smaller grocery retailers seem to produce more value of food waste than larger ones. This supports additional literature observations that larger grocery store formats have a better waste performance [18,22]. A direct cause could be that smaller grocery retailers offer almost the same range of food products as larger ones, especially with regard to fruits and vegetables. Since these products represent a large share of food waste value and since this value is offset with a smaller sales area, the figures for smaller grocery retailers appear higher. As for Cicatiello and Franco [24], this was most likely related to the fact that retailers with a cooked food department had a higher value of food waste, although Filimonau and Gherbin [15] present the contrasting view. In the current study, managers agreed that the retailer's size plays an important role in food waste generation, stating that larger grocery retailers handle more foodstuff varieties and manage larger quantities, which enhances the likelihood of food waste [15]. Thus, the larger the retailers are in terms of size and product range, the more food waste they generate [18]. In future studies along the lines of Teller et al. [18], the value of each food category must be examined and put into the context of store floor square meter coverage, so that a uniform picture can be presented. In addition, the exact food retail categories should be recorded, e.g., $[2,18,19,24,26]$.

For all store owners and manger, the three food commodities with the highest waste share were fruits and vegetables, followed by milk and dairy commodities, and then meat and sausages. The food commodities mentioned in this study are comparable with the ranges given in the articles of the literature review. Here, the highest share was perishable food with a short self-life such as fruits and vegetables, dairy products, meat, and sausages $[2,23,32,38]$. A difference within this study however was that bread and bakery products were not causing such a copious food wastage problem since all interviewed store owners and manager had no bake-off stations, and maintained agreements with suppliers that required they take back these products when past their shelf life. 


\subsection{Causes of Food Waste}

The most coded cause of food waste is the "marketing standard" of the grocery retailers (18), followed by "expiration date" (12), "consumer purchasing behavior" (10), "damage of product/packaging" (8), "ordering problem" (8), "spoilage" (6), "most frequent" (5), and "inadequate storage condition" (4).

The "marketing standard" of the grocery retailers specifies, inter alia, the visual appearance and product characteristics that food products have to meet. They contain the standards set by the government, which retailers must meet by law, but also the standards that each retail organization imposes on themselves. Furthermore, the code also contains the interviewees' description of how they decide when to take products off the shelves, i.e., their managerial decision. Non-compliance with the set marketing standards leads to the complete withdrawal of the delivered food batch. The store owners and manager are not allowed to sell the batch because of non-compliance with the standards, even if the food is sound from a food safety point of view. This means that even the grocery retail store owners actually have to dispose the entire batch, as the food is not allowed to be sold for marketing standard reasons given by the grocery retailer's headquarters. However, since the products are food safe, it is possible for the store owner to donate them. As described above, the store owners record donations in their management systems as outgoing goods, even though they are usually not disposed of, but passed on as food donations. In the management systems it cannot be recorded the exact amounts of donations nor the recipients of the donations. In order to have an overview, the store owners record the food donations and destinations in tables they had developed themselves. All interviewees stated that food banks receive the greatest quantity of donations from product defects or food not matching the marketing standard of the retailer. Examples of such food products are incorrectly printed yoghurt, fried sausages that crack more quickly when roasted, products where one additive was missing, and salmon with too much weight deviation. The marketing standards vary from grocery retailer to grocery retailer and the managerial decisions of the store owners play an important role in what is disposed and donated.

No interviewee sells products after the 'expiration date'. All store owners and manager are aware, that selling food after the best by date is not punishable by law, but in the case of a foodborne illness, is a punishable offence with a fine. The sorting out and deciding which food can still be sold after the expiration date is too much of an effort and risk, and therefore none interviewed sold food past the best by date although much of this may still be consumable. One store owner points out that the best by date does not say anything about the food safety, particularly for food products such as sugar or wine. Gruber et al. [16] report similar observations in their study, where store managers stated that products declared unsalable are often still consumable. The best by date expiration was reported as the biggest cause for food donations in the current study. Shortly before the best by date, the store owners and manager donate these food products. For risk reduction, the food banks provide the consumers with various information on the subject of expiration dates. One store owner does not donate since the food banks require specific procedures and conditions for the donated products, which the store owner considered too time and money consuming to comply with. As from the literature review obtained, other retailer managers report similar experiences [20].

"They [food banks] wanted to sort out the products that we want to donate, i.e., they did not want to take this and they did not want to take that. After three months dealing with this, we were done with it because we simply do not have the time nor money to go with them thru it."

All store owners and manager criticized the "consumer purchasing behavior", as was also reported in studies within the literature review $[15,16,19]$. In this study, the store owners and manager mentioned that customers grab the rearmost items on the shelves to select the products with a longer shelf life. The products with shorter shelf life remain on the shelves until the store owners and manager cannot sell these any more. In addition, the touching of fruits and vegetables by customers to assess firmness and appearance 
is a major problem [17]. This behavior affects the freshness of the products and leaves marks so that the next customer does not want to buy these handled products. Particularly problematic is when customers change their purchasing decision, take the chilled goods out of their shopping cart, and place them elsewhere, in shelves that are not refrigerated. The goods are then found by employees and have to be discarded since the length of time out of the correct temperature environment cannot be verified. Unwanted customer behaviors such as these may be reduced by proper awareness campaigns, with signboards or with announcements via the grocery retailer speakers [49]. According to Kliaugaite and Kruopiene [19] of all identified causes for food waste generation in retail, the majority are linked to customer behavior. Provision of guidance to the customer is one of the main preventive strategies in the grocery retail sector [49].

Over ordering ("ordering problem") is a cause identified in the current study by three out of four store owners and the manager since it is difficult to order food with high accuracy. The demand is not completely predictable since consumers demand a wide variety of food products at any time of the day, any day of the week [16]. To achieve this, the store owners must plan and order goods as accurately as possible to avoid a financial loss. They must also take into account seasonal demand and the provision of weekly offerings. It is therefore not surprising that there are nevertheless sometimes food surpluses in the grocery retail store. This goes in line with Mena et al. [21], who identified forecasting difficulties as a common cause of food waste. It is challenging to reduce the over ordering since consumer demand is difficult to predict and also depends on the weather [32]. One store owner adds that when a product is over-ordered and probably not all of it can be sold, it is crucial to intervene quickly. The store owners should sensitize their employees to recognize this and quickly pass it on so that the store owner can react. Furthermore, the store owners have to find the optimal time to withdraw their products from the shelves [50].

"How do I take care of goods, how am I on the spot to accompany the whole process, to control every day and to counteract certain things. The more attention I pay to this, also supported by my employees, the more possibilities I have to react when I notice that I have a stock surplus."

"Spoilage" is a frequent cause of food disposal in the grocery retail sector, particularly since fruits and vegetable are food products that do not have expiration dates and are perishable. For all interviewees the withdrawal of fruits and vegetables depends on the visual appearance of the products and on the employee's personal assessment. Here the store owners and manager state that the parameters for deciding when a product is spoiled are appearance and freshness, for example, dirt, cracks, dents, wrinkly, peels, or wilted leaves. To access the quality, the employees apply their own empirical values according to long-term experience while asking themselves: "Would I buy this product myself?" In the case of fruits and vegetables, where it is impossible to see from the outside whether they are still edible, they are only discarded if they have visual damages such as dents or cracks. There are no rules for sorting out fruits and vegetables after a certain period of storage at the grocery, retailers and the store owners have to set and establish these rules themselves. Two store owners mentioned that approximately $40 \%$ of fruits and vegetables with visual impairments are sorted out before they reach the grocery retailer since they do not meet marketing standards. If fruits and vegetables do not meet marketing standards and are, for example, crooked or too small for sale and reach the grocery retail store, the store owners donate them. These findings are in line with the literature, fruits and vegetables hold the highest potential to become food waste in grocery retail [15].

The damage of the products or packaging happens mostly during the delivery ("goods in"). Here, heavy items are stored on top of easily damageable items such as fruits and other light products. In the case of damage during the delivery, the supplier has to give proper training to the logistics companies, but this is not the responsibility of the store owners. Particular care needs to be made during the summer months with cooled goods or those that need to be kept within a temperature range during transport. If the cold 
chain is not maintained, the food products can no longer be sold. Concluded agreements with an animal feed and/or biogas are of help to donate the spoiled food. In the store itself, care can be taken by employees to minimize direct handling damage, such as may result from an item falling. This can be easily prevented by store owners and managers issuing instructions to their employees on how to handle food safely. Another rare cause of food waste in the retail sector is inadequate storage conditions, which can be prevented by following storage guidelines.

\subsection{Preventive Strategies}

The most common preventive strategy against food waste in the grocery retail sector taken by the store owners is the "price reduction" (22) of food products. All of the interviewed store owners reduce the price for some of their food products, mainly seasonal articles and chilled products (e.g., diary) by $30 \%$ or by $50 \%$ two to three days before the best by date. The store owner decides independently on each price reduction and for which product line it applies. To standardize this decision, the store owners have established particular procedures when they reduce which products and when they donate which products to food banks. For this, the store owners have to be willing to donate the food. One store owner stated that no donation is necessary because hardly any food is left due to a good managerial planning and after the price reductions. Therefore, the price reduction as a preventive strategy is an effective tool since the customers very well accept it. To achieve even greater consumer acceptance and reduce food waste, the store owner integrated this preventive strategy into the store and sales strategy.

"We try to reduce the price of products that are close to their best by date in order to give certain consumer groups an opportunity to buy cheaper products. [ ... ] The reduced products are located at certain places in the store, so that customers know exactly where to find reduced products. In this way, we already prevent a large part of the decay and waste. That really works quite well."

Two store owners also lower the price of fruits and vegetables that are no longer of high quality, e.g., have few pressure points or dents. Since fruit and vegetables have a high turnover rate and are not in the store longer than three or four days, price reductions for this product range are not very common. Consumers expect freshness when buying fruits and vegetables. They do not accept a price reduction for these products; rather they do not buy them.

"The customer is not ready [for price reduction]. The customer definitely expects freshness for fruits and vegetables."

However, there are certain customer groups that are explicitly waiting for price reductions and are dependent on these price reductions for financial reasons, which may be a reason why this approach works well for the two store owners. The preventive strategy of price discounts of fruits and vegetables is also reported in the literature reviewed $[15,19]$. The store owners mostly distribute the final leftovers of fruits and vegetables to regional farms so that the farms can use them as animal feed or compost material.

The "ordering system" (21) plays an important role for the prevention strategies. With the system, the store owners can look at their current stocks, sales, and write-offs and estimate with these numbers future orders. The store owners are overall satisfied with their ordering system. It for example automatically refuses orders of items that have more than $30 \%$ write-offs, so products that are too low in demand are no longer ordered and food waste can be prevented. However, as the store owners stated, the ordering system needs much maintenance and data recording. It could be improved if it would model weather and season variations to order as accurately as possible. Here, business intelligence systems may be appropriate for intelligent ordering [18,29]. On the other hand, the ordering amount can be changed quickly if an overstocking occurs-but it has to be detected by the store owners, manager, or employees and requires an immediate reaction to get rid of the overstocking. This monitoring by all parties is another preventive strategy 
for food waste. Particularly, if all parties are aware of which products are on the shelves, the final order dates, and their delivery times, food waste can be avoided.

"We can order every day. We order until 13 o'clock and get the products delivered by the next day at 6 o'clock. So you cannot get much shorter than that."

It is important that the employees handle the products in a right way ("right handling" (2)), e.g., stock the food in the shelves according to the best by date and follow the first in first out principle. The tidier, clearer, and better organized the grocery retail store is, the less food waste appears ("others" (4)).

Other important preventive strategies are the "food redistribution" (11) of the withdrawn food products and particular mentioned the donation to employees coded as "employee provision" (6), "food bank" (2), and/or further usage of "animal feed" (11). Here, the store owners must be particular aware of what can or cannot be given to the employees and what can be redistributed. The store owners themselves make these decisions. Statements given by Hermsdorf et al. [20] that food is not redistributed to higher costs resulting of labor and logistic could be confirmed partly by this research (see Section 4.3.).

\subsection{Food Waste Management}

"Form and procedure" (19) for food waste management were very different for each interviewee. While one store owner had a specific agreement with a private collector were the organic waste did not have to be segregated from its plastic or glass packaging, two store owners had to separate the plastic packaging material from organic waste themselves. One collector does not separate the waste, while three others do separate plastic, organic, and residual waste. One store owner provided no information on this. The contracts with collectors varied from private to municipality or by the picking up of the supplier to no information provided by the interviewees.

The "cost" (4) per month for the food waste management collector ranged from $80 €$ up to $300 €$, collection frequency 0.5 to 2 times per week for one to two containers. The store owners and manager did not specify the size of the containers. They merely talked about the number of bins or containers, so that no generally valid conclusions can be drawn about the final amount collected. For all, the further processing of the waste material is depending on the collector, so the interviewees could not provide information about the further processing of the waste by the collector.

Normally store owners should know the type and amount of food waste, the timing of food waste collection, the disposer, and the costs of food waste disposal per month. From our interviews, it appears that food waste management is a very sensitive issue. Most store owners and manager provided vague and estimated information, either because they did not know in detail the contracts with the disposal companies by their parent company or because they did not want to disclose such sensitive information. In addition, fears over possible disadvantages in the public perception may have been a reason for being brisk and rather reluctant to disclose such sensitive information.

In general, the information obtained showed that food waste management is not uniform. Three store owners separated waste, but here, waste separation differed in degree. One overall assumption is that private collectors have better conditions and can pick up larger volumes of waste than municipal collectors can, so their contracts may be more appealing to the store owners. This reasoning could be supported by the costs, which are less than $0.05 \%$ of the turnover. Further investigations would be necessary to obtain meaningful results. None of the articles from the literature review looked closely at the waste collectors and collection strategies, potentially because of the sensitivity of the topic. Only Holweg et al. [26] mentioned three types of waste collectors (residual, organic, and meat waste collectors) but no further information about the price or the waste collector itself is reported. Nevertheless, this topic should be given more attention in future studies, as the actual amounts and types of waste could provide valuable information and lead to recommendations on food waste prevention. 


\subsection{Food Waste Assessment}

All store owners stated in their "self-assessment" (17) that they in principle wish to avoid food waste from a social point of view, but of course, also because they are entrepreneurs and food waste means a financial loss for them. When avoiding food waste, they rate their grocery retail store as average in comparison to other grocery retailers within Germany. They are willing and happy to donate their surplus food to food banks, employees, and/or as animal feed. Since they are the store owners, they are able to decide on the further use of their products before its best by date. Grocery retail store owners are the ultimate decision makers and do not feel as pressured by their franchisor headquarters [16]. This is why, for example, the store owners can also decide to give away surplus food to their employees.

"Yes, many things happen differently in privately owned grocery stores than in retail chains. In a retail chain, you are told from the top. The employees are not allowed to take anything. We usually have a box in the freezer that says "To go." and the one or the other takes something out."

All store owners and the manager must comply with national food safety regulations. Generally assessed (8) the interviewees criticize that a large amount of food is wasted due to these strict controls and regulations. Similar observations are made in the literature review $[12,15,16]$. Here improvements in the national regulations could lead to avoidance of food waste.

Another important issue that the store owners and manager address is the "consumer purchasing behavior" (21). Consumers do not plan their purchases and buy more than is needed. Furthermore, consumers feel entitled to have the total of product range available at all times, even just before the grocery retailer closes, which forces the store owners and manager to overstock. The store owners estimate this overstocking around $30 \%$. In their opinion, the consumer behavior cannot be influenced so they are forced to act in accordance with consumer wishes so as not to lose them as paying customers. These findings go in line with the literature review $[15,17-19,29]$ and are linked to the expiration date (see 3.3). In two to three years, one store owner stated, we will see improvements in the food industry that will contribute to a changed consumer behavior and prevent food waste through a smart system other than the expiration date. This could, for example, be a sticker showing how fresh the product (still) is and that the consumer can safely consume it.

Store owners see "improvement opportunities in the retail sector" (11) to avoid food waste. These improvement opportunities require the full commitment as well as learning and management experience of the store owners and their employees. They have to work hand in hand. Store owners see a great effectiveness in the prevention of food waste when they take truly good care of their business and employees. The better the store owner and store organization, the better the processes work (from the purchase order to "Goods in" via storage to "Goods out"), and the faster situations are recognized and reacted to, and less food waste is generated. Store owners must be aware of the problems associated with food waste and be willing to optimize store operations. To this end, the store owners must train their employees and, above all, make them aware of the issue. Everyone must remain vigilant so that they can react as quickly as possible to avoid food waste and financial shortages.

"I think the emphasis is simply on how I take care of the goods, how I am on the top to accompany the whole thing, to check it and to make sure every day that I am absolutely up to date in terms of freshness, cleanliness, and order. To counteract certain things. And the more attention (... ) we put into this in the form of our employees, the more possibilities I have to react."

Furthermore, store owners stated that they could reduce food waste if they limit product varieties at special times, e.g., just before the store closes, for public holidays, or Sunday ("other improvement opportunities" (7)). This is risky, because consumers have different expectations and buy often more than they actually need, forcing the store owners to meet 
consumer demand [13,15-18,29]. Therefore, in order to not lose customers, store owners overstock, a natural outcome from a financial point of view. Here, special price offers are a significant variable to aid in the prevention or reduction of food waste $[15,16,24,29]$ but the store owners stated that it is even more important to consider potential food waste at the beginning of the product flow. This means that, ideally, the store owners will be able to correctly assess customer requirements accurately over time, based on their experience and ability to adapt. Continuing data collection and monitoring by the store owners could reduce oversupply, over-ordered products, and excessive product diversity. Accordingly, the precise managerial planning and action of the owners play an essential role in avoiding food waste [32].

"Any owner who knows his market, who knows its structure, who knows the buying behavior of his customers, can make the best of his situation. [ ... ] Actually, it is up to each owner to decide how best to deal with food waste. [ . . . ] The focus must be on how I take care of the products, how I am in the store to accompany the whole processes, how I check and see things, how I train my employees."

\section{Conclusions}

This paper investigated the actual scale of food waste in the grocery retail sector within a German region. The results are based on interviews with retail managers that privately own grocery retail stores, and the opinions of one employed store manager. The study reveals, even with the small sample size, that store owners try to reduce food waste and optimize their sales and management strategies with regard to the sale and non-sale of food products since they are personally, and therefore directly affected by the financial loss of food waste as compared to employed managers who receive a fixed salary. The owner's experience and how the grocery retail store is run play an essential role in the optimization of profits and the reduction of food waste.

The results reveal that a majority of food wastage in food retailing in the German region investigated is due to expiration dates and spoilage. Particularly, expired products cause a financial loss for the store owners and manager since products have to be sorted daily before reaching the best by date. Although interviewees say that such products can be safely eaten after the expiration date, they cannot be sold to consumers. Therefore, still edible food has to be disposed of. Although expiration dates and spoilage are the ultimate reason that food commodities are sold at a reduced price just prior to expiration date, or not sold after the date has passed, further causes of food waste include the over-ordering and overstocking of food products, as well as the provision of many product varieties at all times. As the store owners stated, ordering is to a large extent optimized, but the prediction of orders is difficult as consumer demand for various products varies rapidly. If the demand for food products is not as high as estimated and the products remain unsold, an immediate intervention by the store owners and their employees will be required to lower the associated financial loss and associated food waste.

The most appropriate preventive strategy mentioned by the store owners is the price reduction of food products close to their expiration dates. All store owners have established particular procedures to carry this out. With the help of these procedures and the price reduction as preventive strategies, all interviewed store owners can sell the majority of the products and reduce their food waste. Another preventive strategy is redistribution. For this, the store owners have to be willing to donate food and collaborate with food banks. The redistribution of food is not always successful due to small amounts of food surpluses and misunderstandings amongst the parties. Food banks require products from the grocery retailers that are still edible and safe. For the store owners, it can be difficult to manage the redistribution on time, especially for highly perishable products. Such practices require intensive communication and exchange between the two parties, which is more difficult to achieve for larger retail chains or for retailers with a greater physical distance to food banks. If a store owner does not cooperate with food banks, food surplus is made available to employees or may be used as animal feed. In order to use as animal feed, as with food 
banks, a cooperation with a recipient must be established. There is not always a recipient for animal feed available, and store owners are not always interested in establishing such a cooperation. Further causes of food waste reported by the store owners and manager are linked to customer behavior. Unwanted customer behaviors must be prevented by the owners through targeted information provision to consumers [49,51].

The current study has limitations that indicate potential research approaches for future studies. First, the sampling size could have been more diverse, including also privately owned organic grocery retailers in the German region to determine if there is a difference in the management of food waste between conventional and organic grocery retailers. Second, it may be interesting to look at the agreements of the store owners to and with their suppliers as well as with the food waste collectors and their further processing of the collected food waste. Third, the results of this study are not generalizable since the study followed a qualitative research approach with a non-random sampling method. It is important to improve the representativeness and generalizability of the study and thus to explore managerial opinions on food waste and their handling in other German regions with further research. Fourth, future research could look into comparison analysis of owned grocery retail stores in other European countries, considering also the different regulatory structures, which may be in place to reduce food waste in these other nations.

Author Contributions: Conceptualization, I.K.H.; Methodology, I.K.H.; Validation, I.K.H. and T.R.; Formal analysis, I.K.H.; Investigation, I.K.H.; Writing-original draft preparation, T.R.; Writingreview and editing, T.R.; Visualization, I.K.H. and T.R.; Supervision, T.R. All authors have read and agreed to the published version of the manuscript.

Funding: This research received no external funding.

Institutional Review Board Statement: Ethical review and approval were waived for this study, due to not involving personally identifiable data.

Informed Consent Statement: Informed consent was obtained from all subjects involved in the study.

Data Availability Statement: Data are not publicly available, though the data may be made available on request from the corresponding author.

Acknowledgments: We acknowledge support by the Open Access Publishing Fund of Hochschule Fulda-University of Applied Sciences. Special thanks to Autun Purser for native English language editing.

Conflicts of Interest: The authors declare no conflict of interest.

\section{References}

1. United Nations. Sustainable Development Goals. Available online: https://sustainabledevelopment.un.org/?menu=1300 (accessed on 4 November 2020).

2. Bilska, B.; Piecek, M.; Kołożyn-Krajewska, D. A multifaceted evaluation of food waste in a Polish supermarket-Case study. Sustainability 2018, 10, 3175. [CrossRef]

3. Food and Agriculture Organization of the United Nations. Food Loss and Waste and the Right to Adequate Food: Making the Connection. Available online: http:/ / www.fao.org/3/CA1397EN/ca1397en.pdf (accessed on 4 November 2020).

4. Schmidt, T.; Schneider, F.; Leverenz, D.; Hafner, G. Lebensmittelabfälle in Deutschland-Baseline 2015. Thünen Rep. 2015, 71. [CrossRef]

5. Bagherzadeh, M.; Inamura, M.; Jeong, H. Food waste along the food chain. OECD Food Agric. Fish. Pap. 2014, 71. [CrossRef]

6. Rombach, M.; Bitsch, V. Food movements in Germany: Slow food, food sharing, and dumpster diving. Int. Food Agribus. Manag. Rev. 2015, 18, 1-24. [CrossRef]

7. Germany Trade \& Invest. The Food \& Beverage Industry in Germany. Available online: https://www.gtai.de/resource/blob/64 004/e80f4dd7ccd691158b0ee2bc10f8cd6c/industry-overview-food-beverage-industry-en-data.pdf (accessed on 30 October 2020).

8. Bundesvereinigung der Deutschen Ernährungsindustrie. Ernährungsindustrie 2019/2020. Available online: https:/ / www.bveonline.de/presse/infothek/publikationen-jahresbericht/bve-jahresbericht-ernaehrungsindustrie-2020 (accessed on 4 November 2020).

9. Nielsen. Deutschland 2016-Handel, Verbraucher, Werbung. Available online: https://www.nielsen.com/de/de/insights/ report/2016/booklet-handel-verbraucher-werbung-2016/\# (accessed on 30 October 2020). 
10. Swoboda, B.; Foscht, T.; Schramm-Klein, H. Handelsmanagement: Offline-, Online- und Omnichannel-Handel, 4th ed.; Verlag Franz Vahlen: München, Germany, 2019; pp. 100-102.

11. De Moraes, C.C.; de Oliveira Costa, F.H.; Roberta Pereira, C.; da Silva, A.L.; Delai, I. Retail food waste: Mapping causes and reduction practices. J. Clean. Prod. 2020, 256, 120124. [CrossRef]

12. Rosenlund, J.; Nyblom, Å.; Matschke Ekholm, H.; Sörme, L. The emergence of food waste as an issue in Swedish retail. Br. Food J. 2020, 122, 3283-3296. [CrossRef]

13. Buzby, J.C.; Hyman, J. Total and per capita value of food loss in the United States. Food Policy 2012, 37, 561-570. [CrossRef]

14. Mirabella, N.; Castellani, V.; Sala, S. Current options for the valorization of food manufacturing waste: A review. J. Clean. Prod. 2014, 65, 28-41. [CrossRef]

15. Filimonau, V.; Gherbin, A. An exploratory study of food waste management practices in the UK grocery retail sector. J. Clean. Prod. 2017, 167, 1184-1194. [CrossRef]

16. Gruber, V.; Holweg, C.; Teller, C. What a waste! Exploring the human reality of food waste from the store manager's perspective. J. Public Policy Mark. 2016, 35, 3-25. [CrossRef]

17. Cicatiello, C.; Blasi, E.; Giordano, C.; Martella, A.; Franco, S. "If only I could decide": Opinions of food category managers on in-store food waste. Sustainability 2020, 12, 8592. [CrossRef]

18. Teller, C.; Holweg, C.; Reiner, G.; Kotzab, H. Retail store operations and food waste. J. Clean. Prod. 2018, 185, 981-997. [CrossRef]

19. Kliaugaite, D.; Kruopiene, J. Food waste generation and prevention measures in retail sector: A comparative study. EREM 2018, 73. [CrossRef]

20. Hermsdorf, D.; Rombach, M.; Bitsch, V. Food waste reduction practices in German food retail. Br. Food J. 2017, 119, 2532-2546. [CrossRef]

21. Mena, C.; Adenso-Diaz, B.; Yurt, O. The causes of food waste in the supplier-retailer interface: Evidences from the UK and Spain. Resour. Conserv. Recycl. 2011, 55, 648-658. [CrossRef]

22. Lebersorger, S.; Schneider, F. Food loss rates at the food retail, influencing factors and reasons as a basis for waste prevention measures. Waste Manag. 2014, 34, 1911-1919. [CrossRef]

23. Cicatiello, C.; Franco, S.; Pancino, B.; Blasi, E. The value of food waste: An exploratory study on retailing. J. Retail. Consum. Serv. 2016, 30, 96-104. [CrossRef]

24. Cicatiello, C.; Franco, S. Disclosure and assessment of unrecorded food waste at retail stores. J. Retail. Consum. Serv. 2020, 52, 101932. [CrossRef]

25. Cicatiello, C.; Franco, S.; Pancino, B.; Blasi, E.; Falasconi, L. The dark side of retail food waste: Evidences from in-store data. Resour. Conserv. Recycl. 2017, 125, 273-281. [CrossRef]

26. Holweg, C.; Teller, C.; Kotzab, H. Unsaleable grocery products, their residual value and instore logistics. Int. J. Phys. Distrib. Logist. Manag. 2016, 46, 634-658. [CrossRef]

27. Alexander, C.; Smaje, C. Surplus retail food redistribution: An analysis of a third sector model. Resour. Conserv. Recycl. 2008, 52, 1290-1298. [CrossRef]

28. de Hooge, I.E.; Oostindjer, M.; Aschemann-Witzel, J.; Normann, A.; Loose, S.M.; Almli, V.L. This apple is too ugly for me! Consumer preferences for suboptimal food products in the supermarket and at home. Food Qual. Prefer. 2017, 56, 80-92. [CrossRef]

29. Teller, C.; Holweg, C.; Kotzab, H. Stores, edible food waste, and social redistribution. In A Stakeholder Approach and Managing Food; Lindgreen, A., Hingley, M.K., Angell, R.J., Memery, J., Vanhamme, J., Eds.; Gower Publishing Ltd.: Farnham, UK, 2015; pp. 311-325.

30. Aschemann-Witzel, J.; de Hooge, I.; Amani, P.; Bech-Larsen, T.; Oostindjer, M. Consumer-related food waste: Causes and potential for action. Sustainability 2015, 7, 6457-6477. [CrossRef]

31. Devin, B.; Richards, C. Food waste, power, and corporate social responsibility in the Australian food supply chain. J. Bus. Ethics 2018, 150, 199-210. [CrossRef]

32. Brancoli, P.; Rousta, K.; Bolton, K. Life cycle assessment of supermarket food waste. Resour. Conserv. Recycl. 2017, 118, 39-46. [CrossRef]

33. Wohner, B.; Pauer, E.; Heinrich, V.; Tacker, M. Packaging-Related Food Losses and Waste: An Overview of Drivers and Issues. Sustainability 2019, 11, 264. [CrossRef]

34. Aschemann-Witzel, J.; Otterbring, T.; de Hooge, I.E.; Normann, A.; Rohm, H.; Almli, V.L.; Oostindjer, M. The who, where and why of choosing suboptimal foods: Consequences for tackling food waste in store. J. Clean. Prod. 2019, 236, 117596. [CrossRef]

35. Le Borgne, G.; Sirieix, L.; Costa, S. Perceived probability of food waste: Influence on consumer attitudes towards and choice of sales promotions. J. Retail. Consum. Serv. 2018, 42, 11-21. [CrossRef]

36. Young, C.W.; Russell, S.V.; Robinson, C.A.; Chintakayala, P.K. Sustainable retailing-Influencing consumer behaviour on food waste. Bus. Strat. Environ. 2018, 27, 1-15. [CrossRef]

37. Buisman, M.E.; Haijema, R.; Bloemhof-Ruwaard, J.M. Discounting and dynamic shelf life to reduce fresh food waste at retailers. Int. J. Prod. Econ. 2019, 209, 274-284. [CrossRef]

38. Dreyer, H.C.; Dukovska-Popovska, I.; Yu, Q.; Hedenstierna, C.P. A ranking method for prioritising retail store food waste based on monetary and environmental impacts. J. Clean. Prod. 2019, 210, 505-517. [CrossRef]

39. Döring, N.; Bortz, J. Forschungsmethoden und Evaluation in den Sozial- und Humanwissenschaften, 5th ed.; Springer: Berlin/Heidelberg, Germany, 2016; pp. 356-397. 
40. Yin, R.K. Case Study Research and Applications: Design and Methods, 6th ed.; Sage Publications: Los Angeles, CA, USA, 2018.

41. Swoboda, B.; Berg, B.; Dabija, D.-C. International transfer and perception of retail formats. Int. Mark. Rev. 2014, 31, 155-180. [CrossRef]

42. Gummesson, E. Qualitative research in marketing. Eur. J. Mark. 2005, 39, 309-327. [CrossRef]

43. Kaiser, R. Qualitative Experteninterviews. In Konzeptionelle Grundlagen und Praktische Durchführung, 1st ed.; Springer: Wiesbaden, Germany, 2014; pp. 70-88.

44. Gläser, J.; Laudel, G. Experteninterviews und Qualitative Inhaltsanalyse als Instrumente Rekonstruierender Untersuchungen, 4th ed.; VS Verlag für Sozialwissenschaften: Wiesbaden, Germany, 2010; pp. 142-145.

45. Rädiker, S.; Kuckartz, U. Analyse Qualitativer Daten mit MAXQDA. Text, Audio und Video, 1st ed.; Springer: Wiesbaden, Germany, 2019; pp. 44-45.

46. Mayring, P. Qualitative Inhaltsanalyse. Grundlagen und Techniken, 12th ed.; Beltz Verlagsgruppe: Weinheim, Germany, 2015; pp. 50-114.

47. Kuckartz, U. Qualitative Inhaltsanalyse. Methoden, Praxis, Computerunterstützung, 4th ed.; Beltz Juventa: Weinheim, Germany, 2018; pp. 174-175.

48. Mena, C.; Terry, L.A.; Williams, A.; Ellram, L. Causes of waste across multi-tier supply networks: Cases in the UK food sector. Int. J. Prod. Econ. 2014, 152, 144-158. [CrossRef]

49. Lipinski, B.; Hanson, C.; Lomax, J.; Kitinoja, L.; Waite, R.; Searchinger, T. Reducing Food Loss and Waste; Working Paper, Installment 2 of Creating a Sustainable Food Future; World Resource Institute: Washington, DC, USA, 2013.

50. Giuseppe, A.; Mario, E.; Cinzia, M. Economic benefits from food recovery at the retail stage: An application to Italian food chains. Waste Manag. 2014, 34, 1306-1316. [CrossRef]

51. Richter, B.; Bokelmann, W. Approaches of the German food industry for addressing the issue of food losses. Waste Manag. 2016, 48, 423-429. [CrossRef] 